\title{
Current Status of Silicon Materials Research for Photovoltaics Applications
}

T. F. Ciszek

April 1985

Prepared for the.

SPIE Technical Symposium East '85, Arlington, $V A$,

8-12 April 1985

Prepared under Task No. 3448.10

FTP No. 521

Solar Energy Research institute

A Division of Midwest Research Institute

1617 Cole Boulevard

Golden, Colorado 80401

Prepared for the

U.S. Department of Energy

Contract No. DE-AC02-83CH10093 


\title{
NOTICE
}

This report was prepared as an account of work sponsored by the United States Government. Neither the United States nor the United States Department of Energy, nor any of their employees, nor any of their contractors, subcontractors, or their employees, makes any warranty, expressed or implied, or assumes any legal liability or responsibility for the accuracy, completenesś or usefulness of any information, apparatus, product or process disclosed, or represents that its use would not infringe privately owned rights.

\author{
Printed in the United States of America \\ Available from: \\ National Technical Information Service \\ U.S. Department of Commerce \\ 5285 Port Royal Road \\ Springfield, VA 22161 \\ Price: Microfiche A01 \\ Printed Copy A02
}

Codes are used for pricing all publications. The code is determined by the number of pages in the publication. Information pertaining to the pricing codes can be found in the current issue of the following publications, which are generally available in most libraries: Energy Research Abstracts. (ERA); Government Reports Announcements and Index (GRA and I); Scientific and Technical Abstract Reports (STAR); and publication. NTIS-PR-360 available from NTIS at the above address. 
Current status of silicon materials research for photovoltaic applications

$$
\text { T. F. Ciszek }
$$

Solar Energy Research Institute, Solid State Research Branch Building $16 / 3,1617$ Cole Boulevard, Golden, Colorado, 80401

\section{Abstract}

The desire for high solar cell efficiencies has been a strong factor in determining the course of recent silicon crystal growth research efforts for photovoltaics. This review, therefore, focuses on single-crystal, dislocation-free ingot growth methods (Czochralski growth, float zoning, and cold crucible growth) and on sheet growth technologies, generally multicrystalline, that have achieved moderately high ( $>13.58$ ) laboratory-scale efficiencies. These include dendritic web growth, growth from capillary dies, edge-supported pulling, ribbon-against-drop growth, and a recent technique termed crucible-free horizontal growth. Silicon ribbon crystals provide a favorable geometry and require no wafering, but they contain defects that limit solar cell performance. Growth processes, their current status, and cell efficiencies are discussed. Silicon material process steps before and after crystal growth are described, and the advantages of silicon are presented.

\section{Introduction}

Crystalline silicon is one of a number of materials currently being investigated for photovoltaic (PV) use. Some of the favorable characteristics it possesses for PV applications are abundance, salubrity, an established technology base, easy surface passivation, high demonstrated cell efficiencies, and moderate basic material cost. On the negative side are the requirement for active-layer thicknesses approaching 100 microns (to absorb most of the impinging light) and the escalation of material cost associated with crystal growth and processing.

The abundance of silicon in the earth's crust is shown in Table 1 along with that of other elements that are potentially useful for photovoltaic devices. 1 Quartz is the major ore that silicon is extracted from. It does not naturally occur as an element. Abundance is important for a PV materiai if large-scale terrestrial use is envisioned, because replacing even 108 of conventional electrical power generation with photovoltaic power generation requires about 2 to .40 million tons of crude semiconductor material. The current annual elemental metallurgical-grade silicon production capacity is only about $0.5 \mathrm{million}$ tons, and this far exceeds the production of other semiconductor materials.

Table 1. Abundance, by weight percent in the earth's crust, of some elements used in PV devices

Element Concentration (wt 8$)$ Element Concentration (wt $z)$

\begin{tabular}{lcll}
\hline Si & 27.7 & Ga & 0.002 \\
$\mathrm{Al}$ & 8.1 & $\mathrm{As}$ & 0.0005 \\
$\mathrm{Mg}$ & 2.1 & $\mathrm{Sb}$ & 0.0001 \\
$\mathrm{P}$ & 0.1 & $\mathrm{Cd}$ & 0.00002 \\
$\mathrm{~S}$ & 0.05 & $\mathrm{In}$ & 0.00001 \\
$\mathrm{Zn}$ & 0.01 & $\mathrm{Se}$ & 0.000009 \\
$\mathrm{Cu}$ & 0.007 & $\mathrm{Te}$ & 0.0000002 \\
\hline
\end{tabular}

In large-scale applications (i.e., when quantities greater than those resulting from by-products of other mining operations are required), the extraction costs for less abundant elements greatly exceed those for abundant elements. For example, platinum has an abundance of 0.0000005 wtg (midway between $S e$ and $T e$ ) and the energy cost for mining and milling is $\$ 2,200,000 / \mathrm{MT}$, while iron has an abundance of 5.68 and costs $\$ 2 / \mathrm{MT}$ for the energy to mine and mill it. 2 An analogous situation is likely to occur for elements used in large-scale pv applications.

Over the past 35 years, a significant technology base for silicon processing has developed. A large body of knowledge thus exists on materials preparation and handling, materials compatibility, crystal growth, materials properties, defect characteristics, device fabrication, and reliability. One important aspect of this development is the 
compatibility of $\mathrm{SiO}_{2}$ with crystalline silicon, both because of the device processing applications and because of the surface passivation properties of $\mathrm{SiO}_{2} \mathrm{films}_{\text {on }}$ silicon. The latter is particularly pertinent to high-efficiency solar cells, because it provides a means to control surface recombination velocity of generated carriers. Other semiconductor systems generally do not easily form native passivarion layers. Fortunately, neither silicon nor $\mathrm{SiO}_{2}$ are toxic, whereas many compound semiconductors used in pv devices contain toxic components. This has also contributed to the fast development and widespread use of silicon as a semiconductor.

Several researchers have achieved air mass 1 (AMl) cell efficiencies greater than 18 \& with silicon, and even 19.18 has been reported. 3 Typically, the higher efficiencies were obtained using float-zoned silicon crystals with a high minority carrier iifetime. Recent analysis 4 has shown that efficiencies of this magnitude may be necessary for economical deployment of large, terrestrial power generating systems, because of high balance of system costs.

Although silicon cells must be nearly 100 microns thick for efficient light utilization, the market price for this quantity of pure (>99.9998 or $5 \mathrm{~N}$ ) polycrystalline silicon at $\$ 80 / \mathrm{kg}$ is only $\$ 19 / \mathrm{m}^{2}$, or $\$ 0.10 / \mathrm{W}_{\mathrm{p}}$ (at 198 peak efficiency). In comparison, a thin-film heterojunction solar cell such as cds/CuInse 2 is composed of a 2.5 -micron cds layer with a price of $\$ 4.70 / \mathrm{m}^{2}$ (based on a current market price of $\$ 395 / \mathrm{kg}$ for $5 \mathrm{~N}$ pure powder material), and a 3.3-micron CuInse 2 layer with a price of $\$ 420 / \mathrm{kg}$ (based on current market prices of $\$ 250 / \mathrm{kg}$ for $5 \mathrm{~N}$ pure $\mathrm{Cu}, \$ 900 / \mathrm{kg}$ for $5 \mathrm{~N}$ pure In, and $\$ 130 / \mathrm{kg}$ for $5 \mathrm{~N}$ pure Se) or $\$ 7.90 / \mathrm{m}^{2}$. $\mathrm{It}$ also requires a substrate (typically alumina, which could probably have a market price as low as $\$ 7.00 / \mathrm{m}^{2}$ in large quantities). The total selling price for the substrate plus active layers is $\$ 19.60 / \mathrm{m}^{2}$, or $\$ 0.20 / \mathrm{w}_{\mathrm{p}}$ (at 108 peak efficiency). While the basic pure materials cost of the silicon cell is only about one-half that of the thin-film cell, both technologies escalate the materials costs during frocessing because the utilization efficiency is $<1$. The cost escalation for thin film cells has not been fully analyzed, because the technology is young and evolving. However, it is generally thought that more efficient material utilization and lower process energy costs are possible with thin-film technologies.

Watering (diamond abrasives)

Pure silicon crystal $\$ 400 / \mathbf{k g}$

Crystal growth $\left(1500^{\circ} \mathrm{C}\right)$

Pure polycrystalline silicon $(>\$ 80 / \mathbf{k g})$

Vapor deposition -

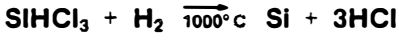

Pure chlorosilane (e.g. $\mathrm{SIHCl}_{3}, \$ 20 / \mathrm{kg}$ of SI)

\begin{tabular}{|c|c|}
\hline & Distillation \\
\hline \multicolumn{2}{|c|}{ Chlorosilanes } \\
\hline & $\begin{array}{l}\text { Fluidized bed reaction - } \\
\mathrm{SI}+\mathrm{HCl} \longrightarrow \mathrm{H}_{2}+\mathrm{SiHCl}_{3}, \mathrm{SiCl}_{4}, \mathrm{SiH}_{2}\end{array}$ \\
\hline \multicolumn{2}{|c|}{$\begin{array}{l}\text { Metallurgical grade silicon } \\
\qquad(\$ 2 / \mathbf{k g})\end{array}$} \\
\hline & $\begin{array}{l}\text { Coke reduction in an arc furnace - } \\
\mathrm{SIO}_{2}+\mathrm{C}-\mathrm{Si}+\mathrm{CO}, \mathrm{CO}_{2}, \mathrm{SiC} \text {, etc. }\end{array}$ \\
\hline Sand ( & $\left(\mathrm{SiO}_{2}\right)$ \\
\hline
\end{tabular}

Figure 1. Process sequence for silicon, showing selling price at various stages.
The escalation of material prices for conventional silicon technology is depicted in the process sequence diagram of Figure 1 , both for the steps preceding and the steps succeeding the pure polycrystalline stage discussed above. The diagram also briefly describes the technology steps required to progress from one process stage to the next. The selling price of the silicon increases by a factor of 15 as processing proceeds from the pure polycrystalline stage to polished single-crystal wafers that are ready for device fabrication. Lower-cost ingot crystal growth methods, higher-lifetime crystal ingots, silicon sheet growth, and alternatives to chemical/mechanical polishing are some of the research areas designed to help obtain higher power/cost ratios in silicon PV cells. This review of crystal growth methods will cover ingot growth techniques that obtain relatively high solar cell conversion efficiencies. These are Czochralski (CZ) growth, float zoning (FZ). and cold crucible (CC) growth. Sheet growth technologies, generally multicrystalline, that have achieved moderately high ( $>13.58$ ) laboratory efficiencies will also be reviewed. The latter include dendritic web growth (web), growth from capiilary dies (EFG/CAST), edge supported pulling (ESP), ribbon-against-drop (RAD) growth, and a recent technique termed crucible-free horizontal (CFH) growth. 
Ingot crystal growth

Most dislocation-free, semiconcuctor-grade silicon crystals are grown by the Cz method, although an estimated 10\%-20? are FZ grown. No other techniques are used in production. Another method, cold crucible growth, has recently been applied to both [100] and [11l] dislocation-free silicon crystals. 5 Schematic diagrams of these three methods are presented in Figure 2. Casting and directional solidification by the Bridgman method are widely used to produce large, multigrain ingots for PV use, but lower solar cell efficiencies are obtained as a result of grain boundary and impurity effects. Table 2 compares some characteristics of ingots produced by the five methods. Only the dislocation-free methods ( $C Z, F Z$, and CC) will be discussed in more detail here.

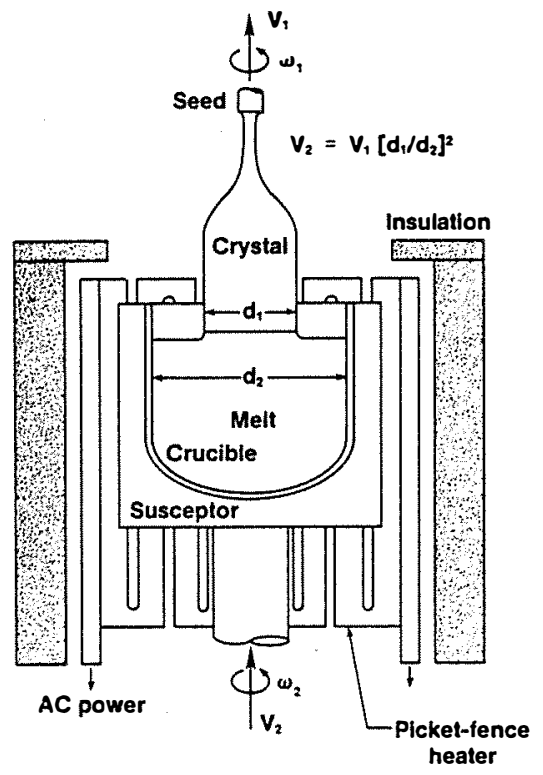

Figure 2. Dislocation-free sil
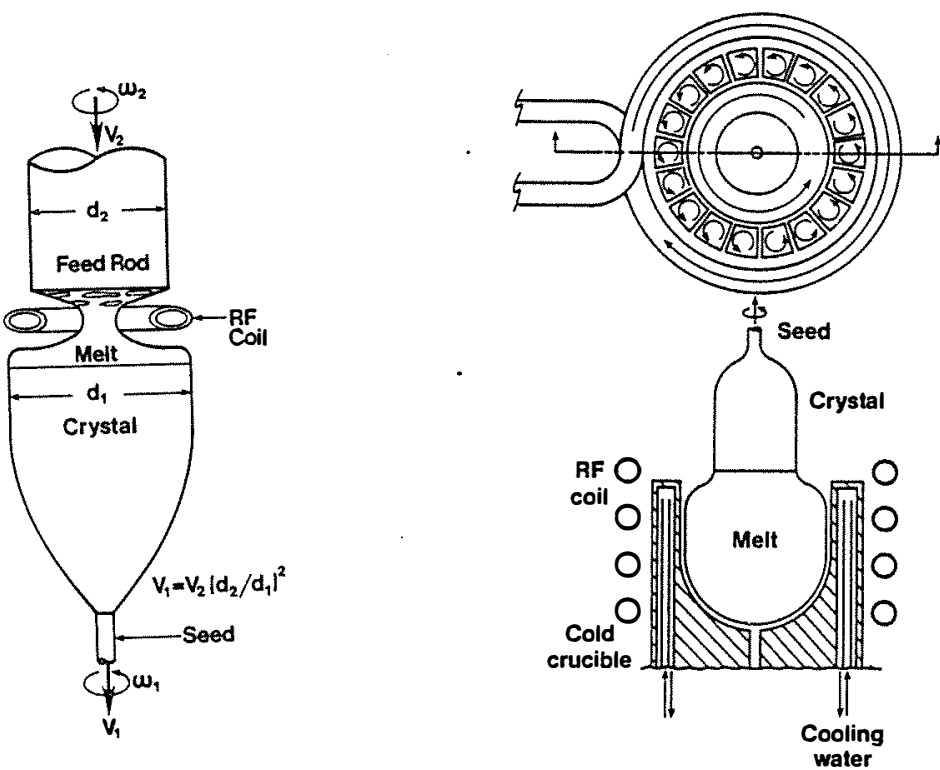

growth methods: CZ (left), FZ (middle), and CC (right).

Table 2. Some characteristics of five silicon ingot crystallization methods

\begin{tabular}{|c|c|c|c|c|c|c|c|}
\hline Method & $\begin{array}{c}\text { Diameter } \\
(\mathrm{mm})\end{array}$ & $\begin{array}{c}\text { Growth Rate } \\
(\mathrm{mm} / \mathrm{min})\end{array}$ & $\begin{array}{c}\text { Crystal } \\
\text { structure }\end{array}$ & Technology & Purity & $\begin{array}{l}\text { Relative } \\
\text { Effici }\end{array}$ & $\begin{array}{l}\text { ecell } \\
\text { iency }\end{array}$ \\
\hline $\mathrm{CZ}$ & 150 & $1-2$ & $\begin{array}{l}\text { dislocation- } \\
\text { free }\end{array}$ & high & moderate & & 1 \\
\hline F Z & 125 & $2-4$ & $\begin{array}{l}\text { dislocation- } \\
\text { free }\end{array}$ & $\begin{array}{l}\text { very } \\
\text { high }\end{array}$ & $\begin{array}{l}\text { very } \\
\text { high }\end{array}$ & 1 & -1.2 \\
\hline $\mathrm{CC}$ & 20 & $1-3$ & $\begin{array}{l}\text { dislocation- } \\
\text { free }\end{array}$ & high & high & 1 & -1.1 \\
\hline Bridgman & 340 & $0.1-5$ & $\begin{array}{l}\text { multiple } \\
\text { grains }\end{array}$ & low & $\begin{array}{l}\text { moderate } \\
\text { to low }\end{array}$ & 0.6 & -0.9 \\
\hline Casting & 340 & $1-2$ & $\begin{array}{c}\text { multiple } \\
\text { grains }\end{array}$ & low & $\begin{array}{l}\text { moderate } \\
\text { to low }\end{array}$ & 0.6 & -0.8 \\
\hline
\end{tabular}

Silicon crystal growth has been conducted by the Teal-Little adaptation of Czochralski's growth method since 1950. It is the most common and widely known of the silicon growth methods. Silicon is melted in a quartz crucible at temperatures slightly above $1412^{\circ} \mathrm{C}$, the silicon melting temperature. Because this temperature is well above the quartz softening temperature, the crucible rests in a rigid graphite susceptor. A cylindrical, graphite, picket-fence resistance heater surrounds the susceptor and operates at input power levels up to $150 \mathrm{kVA}$. For $150-\mathrm{mm}$ crystal diameters, crucible diameters in the range of $300-400 \mathrm{~mm}$ are 
used to contain silicon charges weighing 20-60 kg. The crucible rotates at a few rpm and is moved upward at an approximate rate of $v_{2}=v_{1}\left(d_{1} / d_{2}\right)^{2}$ during crystal growth to maintain the solidifying interface at an optimum axial position in the heater. $v_{1}$ is the crystal pulling speed (usually in the range 1 to $3 \mathrm{~mm} / \mathrm{min}$ ), $\mathrm{d}_{1}$ is the crystal diameter, and $\mathrm{d}_{2}$ is the crucible diameter. An inert ambient is maintained in the growth chamber. Crystal growth is initiated by touching a small-diameter seed crystal to the free liquid surface and then moving it upward to solidify silicon on the seed. A thin necked region is grown to eliminate dislocations generated from the seed/melt contact shock. Then the crystal is widened to full diameter by adjusting the heater power and pulling speed. An automatic control system then maintains a nearly constant diameter. Figure 3 shows several flat-top, [100] oriented crystals grown by the author using the process just described.

Current commercial growth systems can produce crystal lengths up to $1 \mathrm{~m}$ or diameters up to 200 $\mathrm{mm}$ (generally not simultaneously). Crucible costs and slow growth rates are the main economic drawbacks of $\mathrm{CZ}$ growth. The relatively low minority carrier lifetimes of cz-grown crystals (compared with FZ or CC crystals) limit solar cell performance. In addition to metallic impurity incorporation from impurities in the quartz crucible, $C z$ crystals contain a large concentration of oxygen (on the order of $10^{18} / \mathrm{cm}^{3}$ ) which originates from cfucible dissolution and carbon (up to $2 \times 1017 / \mathrm{cm}^{3}$ ) which results from the reaction of graphite hot-zone components with silicon oxides. These impurities cause microdefects and lowered minority carrier lifetimes in the macroscopically dislocation-free $\mathrm{CZ}$ crystals. The use of $\mathrm{Si}_{3} \mathrm{~N}_{4}$-coated crucibles, as well as crystal growth in magnetic fields (to reduce crucible dissolution) is being explored for controlling detrimental impurity effects. The latter can be expected to reduce, but not to eliminate, oxygen-related defect generation.

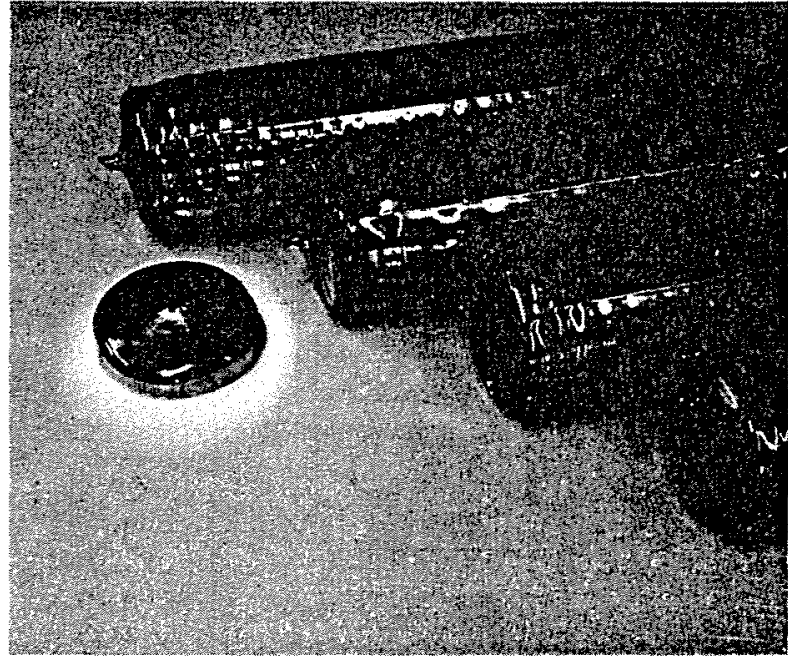

Figure 3. Several dislocation-free [100] Cz crystals with flat-top transitions.

FZ growth requires neither a crucible nor hot graphite components near the liquid silicon. Induction heating at frequencies in the 1-3 MHz range is used to melt the silicon, and the liquid does not contact any foreign material. Carbon and oxygen concentrations are two orders of magnitude less than those of $\mathrm{CZ}$ crystals. In additior, there are no crucible costs and the crystal growth rates are higher than Cz rates by about a factor of 2 . However, there are also disadvantages. Some of these are the lower efficiency of induction heating; the requirement for smooth, crack-free polycrystalline feed material; harsher thermal gradients; complexities associated with a liquid zone suspended between solid rods; and the unstable equilibrium of a heavy crystal resting on a thin neck.

Extremely low metallic impurity concentrations can be achieved by multiple zone passes and the consequent purification by segregation and evaporation. We have achieved minority carrier lifetimes greater than 300 microseconds in heavily doped $(0.4-0.5 \mathrm{ohm}-\mathrm{cm}) \mathrm{Fz}$ crystals by muitipassing. Such material allows large open-circuit solar cell voltages and high cell efficiencies. FZ silicon is the best available material for high-efficiency si solar cells. Figure 4 shows a 75-mm-diameter Fz crystal being grown in our laboratory.

Cold crucible crystal growth is another method that shows some promise of yielding higher cell efficiencies than conventional CZ growth. Figures 2 and 5 show schematic and actual crystal growth by this technique. An induction heating coil coaxially surrounds the cold crucible. The vertical walls of the crucible are composed of closely spaced, electrically isolated, water-cooled copper (or gold-plated copper) fingers that have approximately square cross sections. Each finger acts as a stepdown transformer, and the coil current induces radio frequency (RF) currents to flow in the fingers. The finger currents in turn induce a current to flow in the silicon charge. Ohmic resistance to this current flow causes heating and melting of the charge. At the inside wall of the crucible, the instantaneous current cirections in the fingers and in the charge are opposed (as shown in Figure 2 ); thus, a force caused by magnetic repulsion pushes the silicon melt away from the fingers.

In our laboratory, we have grown both [111] and [100] dislocation-free silicon crystals from a cold crucible without auxiliary heating. 5 such crystals have oxygen and carbon contents (measured by infrared spectroscopy) similar to those of float-zoned crystals. We used neutron activation analysis to determine gold and copper contents in a [100], 2.5 ohm-cm, dislocation-free silicon crystal grown from a gold-plated copper cold crucible. Low levels of $0.14 \mathrm{ppb}$ (weight) for gold and $15 \mathrm{ppb}$ (weight) for copper were found. Minority 
carrier lifetimes between those of FZ crystals and those of CZ crystals were observed. For example, a p-type [111] dislocation-free crystal of approximately 100 ohm-cm resistivity had a 195-microsecond lifetime.

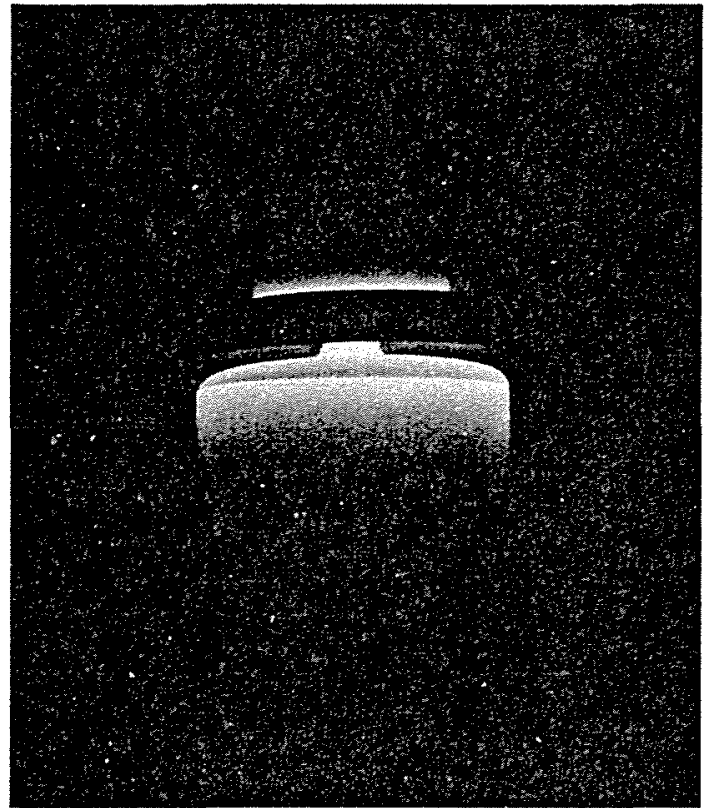

Figure 4. Float-zone growth of silicon.



Figure 5. Dislocation-free cold-crucible growth.

We observed that solar cell efficiencies for cold crucible crystals were higher than those for coprocessed, conventional CZ crystals. Mesa array cells $0.1 \mathrm{~cm}^{2}$ in area were fabricated simultaneously on a wafer. Individual cells in an array were isolated by an etched moat. To better determine material effects on cell efficiency, anti-reflection (AR) coatings were not used. Table 3 gives statistics on cell performance. Cell results from several wafers are included. In all cases, the open-circuit voltage (Voc), short-circuit current ( $\mathrm{J}_{S C}$ ), and cell efficiency were higher for the cold crucible material. The fill factors were nearly equal within the standard deviation (shown in parentheses) of the measurements. Under ELH illumination at $25^{\circ} \mathrm{C}$, the average control efficiency was $10.98 ;$ the cold crucible cells were 11.78 efficient. Under xenon solar simulator illumination at $28^{\circ} \mathrm{C}$, the control cells were 10.28 efficient, while the cold-crucible cells had an average efficiency of $10.6 \%$. Good AR coatings can increase the cell efficiencies by at least 438 .

Table 3. Solar cell current/voltage characteristics for some diffused-junction $\mathrm{n} / \mathrm{p}$ devices with a total area of $0.10 \mathrm{~cm}^{2}$.

\begin{tabular}{|c|c|c|c|c|c|c|}
\hline $\begin{array}{l}\text { Cell Measurement } \\
\text { Conditions }\end{array}$ & $\begin{array}{c}\text { Cell } \\
\text { Description }\end{array}$ & $\begin{array}{l}\text { No. of } \\
\text { Cells }\end{array}$ & $\begin{array}{c}V_{\text {oc }} \\
(\mathrm{mV})\end{array}$ & $\begin{array}{c}J_{\mathrm{ac}} \\
\left(\mathrm{mA} / \mathrm{cm}^{2}\right)\end{array}$ & $\begin{array}{l}\mathbf{F F} \\
(\%)\end{array}$ & $\begin{array}{l}\text { Eff. } \\
(\%)\end{array}$ \\
\hline $\begin{array}{l}100 \mathrm{~mW} / \mathrm{cm}^{2}, \mathrm{ELH} \\
\text { lamps, } 25^{\circ} \mathrm{C} \text {, no } \\
\text { AR coating, } 0.1 \\
\mathrm{~cm}^{2} \text { cell area }\end{array}$ & $\begin{array}{l}\text { Cz Control } \\
\text { Cold Crucible }\end{array}$ & $\begin{array}{l}3 \\
8\end{array}$ & $\begin{array}{l}573( \pm 1) \\
579( \pm 3)\end{array}$ & $\begin{array}{l}23.8( \pm .2) \\
24.9( \pm .4)\end{array}$ & $\begin{array}{l}80( \pm 1) \\
81( \pm 1)\end{array}$ & $\begin{array}{l}10.9( \pm .3) \\
11.7( \pm .2)\end{array}$ \\
\hline $\begin{array}{l}100 \mathrm{~mW} / \mathrm{cm}^{2} \\
\text { SERI filtered } \\
\text { Xenon simula- } \\
\text { tor } 28^{\circ} \mathrm{C} \text {, no } \\
\text { AR coating, } \\
0.1-\mathrm{cm}^{2} \text { cell area }\end{array}$ & $\begin{array}{l}\text { Cz Control } \\
\text { Cold Crucible }\end{array}$ & $\begin{array}{l}3 \\
4\end{array}$ & $\begin{array}{l}561( \pm .4) \\
568( \pm .7)\end{array}$ & $\begin{array}{l}22.9( \pm .1) \\
23.5( \pm .4)\end{array}$ & $\begin{array}{l}79.4( \pm .3) \\
78.9( \pm .2)\end{array}$ & $\begin{array}{l}10.2( \pm .1) \\
10.6( \pm .2)\end{array}$ \\
\hline
\end{tabular}


Wafering of ingots results in a 458-508 loss of material as silicon sawdust. A typical material yield is $1 \mathrm{~m}^{2}$ of surface area per $\mathrm{kg}$ of silicon. Internal diameter (ID) diamond saws can can produce 2000 wafers/m from a $100 \mathrm{~mm}$ diameter ingot at an area rate of about $0.15 \mathrm{~m}^{2} / \mathrm{h}$. In addition to material waste, then, the slow sawing rates are a concern. Multiblade slurry sawing (MBS) is a possible alternative to inside diameter sawing. This

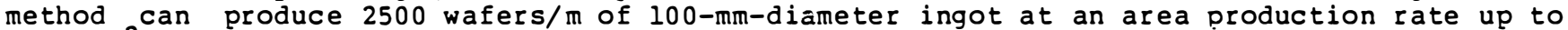
$0.007 \mathrm{~m}^{2} / \mathrm{h}$ per blade. Thus, the area production rate of a MBS 22-biade pack is about equivalent to that of an ID saw. The depth of abrasive damage associated with MBS sawing is typically 5-6 microns.

\section{Silicon sheet growth}

The primary advantage of silicon sheet growth is that it eliminates the material waste associated with ingot growth as well as the costs of the wafering and mechanisal polishing operations. The disadvantage is that currently available sheet growth methods do not produce high-quality material. Dislocations and twins are present in sheets grown by all processes, and most produce material with grain boundaries. These defects reduce the minority carrier lifetime and solar cell efficiencies relative to those obtained with dislocation-free silicon. A number of sheet growth methods have been investigated; Table 4 lists them in chronological order. In this discussion, we will cover only those methods that have achieved cell efficiencies $>13.58$ with an $A R$ coating or, equivalently, $>9.58$ without an AR coating. EFG, PAD, ESP, weh, and CFH processes have produced sheets that attained efficiencies in this range. We will examine these five processes in more detail. They are shown schematically in Figures 6-10.

Table 4. A chronological listing of some silicon sheet growth techniques

Dendritic web growth (web, 1963)

Stepanov growth (1967)

Edge-defined, film-fed growth (EFG, 1972)

Horizontal ribbon growth (HRG, 1975)

Ribbon-against-drop (RAD, 1976)

Ribbon-to-ribbon zoning (RTR, 1976)

Silicon on ceramic (SOC, 1976)

Capillary action shaping tech. (CAST, 1977)

Contiguous capillary coating (CCC, 1977)

Inverted Stepanov growth (1977)
Roller quenching (1979)

Low angle silicon sheet (LASS, 1980)

Edge-suppor ted pulling (ESP, 1980)

Interface-controlled crystal-

lization (ICC, 1981)

Supported web (S-web, 1982)

Melt spinning (1982)

Ramp-assisted foil casting technique (RAFT, 1984)

Crucible-free horizontal growth ( $\mathrm{CFH}, 1985)$



Figure 6 . Schematic of EFG capillary die growth.



Figure 7. Schematic of the ribbon-against-drop (RAD) silicon growth process. 


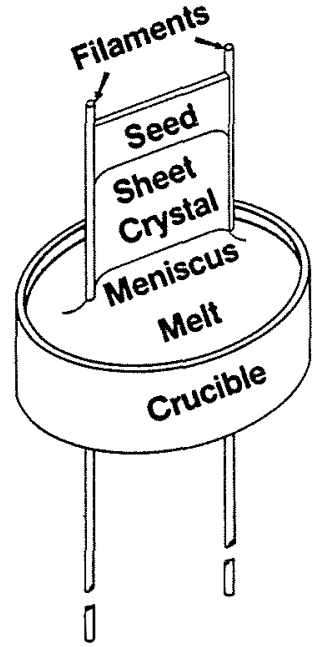

Figure 8 . Schematic of the edgesupported pulling (ESP) process.

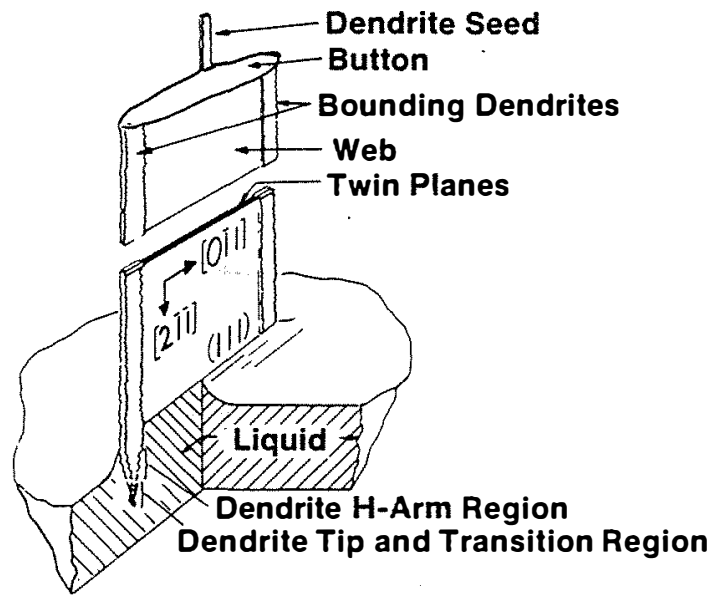

Figure 9. Schematic of web growth.
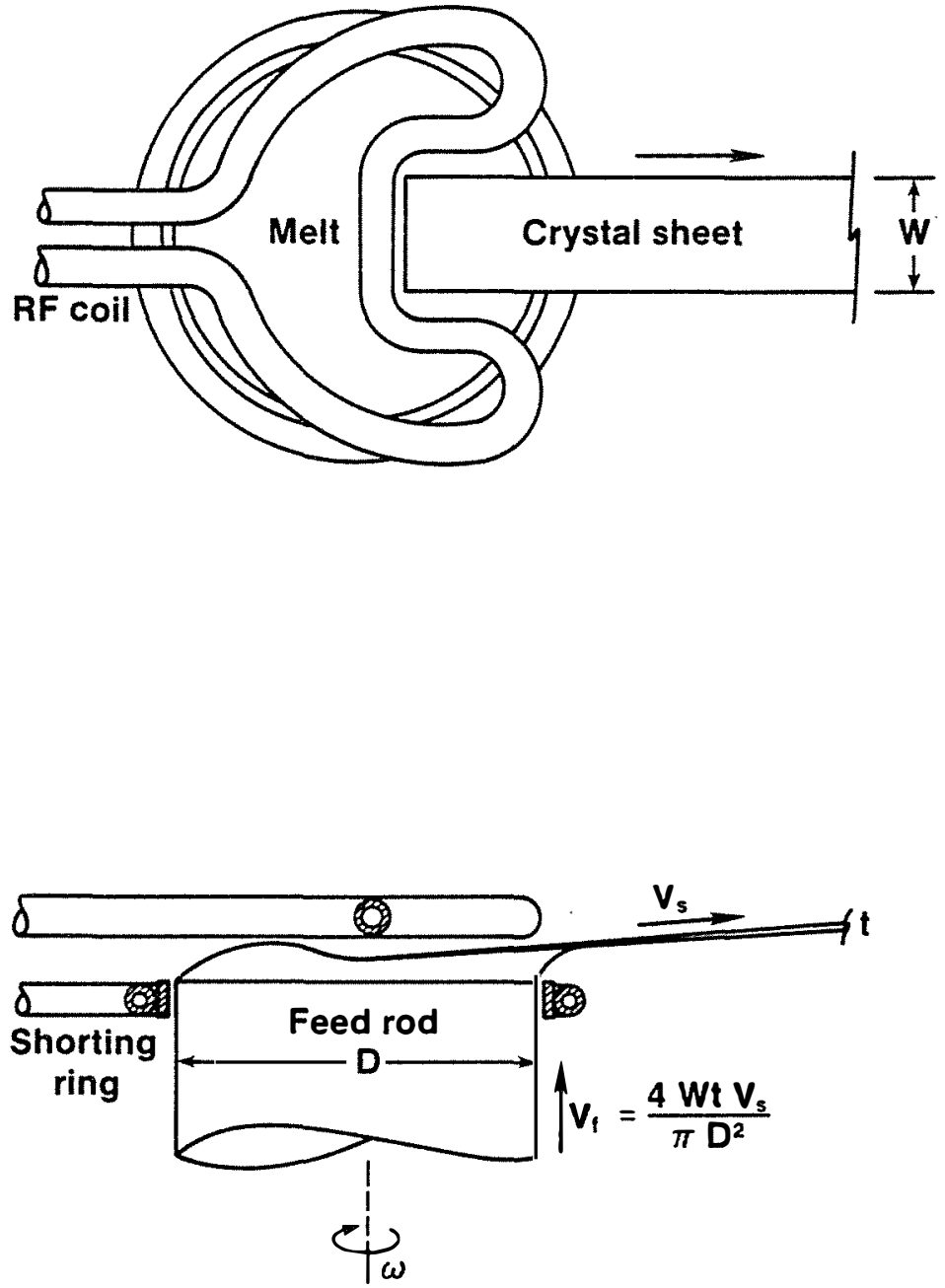

Figure 10. Schematic of crucible-free horizontal (CFH) silicon ribbon growth process.

Growth of sheets from a capillary die is shown in Figure 6. Both EFG 6 and CAST $^{7}$ methods use this concept. The die is usually made of graphite. Liquid silicon rises up capillary slots in the shaping die and spreads across the die top. The outer edges of the die top define the base of the meniscus from which the sheet solidifies. The capillary plate separation is in the range of $0.2-0.5 \mathrm{~mm}$. The meniscus height is typically $0.2-0.4 \mathrm{~mm}$ for EFG growth and $0.5-0.8 \mathrm{~mm}$ for CAST growth (achieved via a specially shaped die top). Close proximity of the die top to the ribbon's solid/liquid interface requires good thermal control to avoid freeze-out of the growing ribbon to the die. The narrow capillary channel reduces the effective segregation coefficient to nearly one for this process. Therefore, reasonably pure silicon must be used. One impurity inherent to the process is carbon. Die dissolution saturates the melt with carbon which is rejected at the solid/liquid growing interface, but cannot readily diffuse back down the die channel. The meniscus region therefore becomes supersaturated and SiC crystallite particles form at the die top. Eventually the particles attach to the growing ribbon. Some progress has been made in controlling their attachment.

A novel application of EFG growth is the formation of closed, nine-sided cylindrical polygons in which each side is $5 \mathrm{~cm}$ wide. In this way, an effective $r$ ibbon width of $45 \mathrm{~cm}$ is obtained, and since there are no edges, many of the control problems related to ribbon edge geometry are eliminated. Table 5 summarizes some of the stability and purity characteristics of EFG ribbons, and Table 6 presents growth characteristics and solar cell performance (the first number for cell efficiency is the best achieved efficiency, and the second is a typical or average current efficiency value). 
Table 5. Stability and purity characteristics of sheet growth methods that can produce greater than $13.5 \%$ efficient solar cells

\begin{tabular}{|c|c|c|c|c|c|}
\hline & EFG & ESP & RAD & WEB & $\mathrm{CFH}$ \\
\hline $\begin{array}{l}\text { Meniscus height } \\
(\mathrm{mm})\end{array}$ & 0.5 & 6 & 6 & 6 & a few $\mathrm{mm}$ \\
\hline $\begin{array}{c}\text { Thermal control } \\
\text { (degrees C) }\end{array}$ & 1 & $1-10$ & $1-10$ & $0.1-1$ & $?$ \\
\hline $\begin{array}{l}\text { Surface } \\
\text { morphology }\end{array}$ & $\begin{array}{l}\text { rippled, } \\
\text { striated }\end{array}$ & $\begin{array}{l}\text { smooth, } \\
\text { bowing }\end{array}$ & $\begin{array}{c}\text { flat } \\
(2 \text { microns })\end{array}$ & $\begin{array}{l}\text { very } \\
\text { smooth }\end{array}$ & irregular \\
\hline $\begin{array}{l}\text { Impurity } \\
\text { sources }\end{array}$ & $\begin{array}{l}\text { die, } \\
\text { crucible }\end{array}$ & filaments & $\begin{array}{l}\text { carbon } \\
\text { ribbon }\end{array}$ & $\begin{array}{l}\text { hot zone } \\
\text { parts }\end{array}$ & $\begin{array}{l}\text { no major } \\
\text { sources }\end{array}$ \\
\hline $\begin{array}{l}\text { Impurity } \\
\text { segregation }\end{array}$ & $k(e)$ near 1 & $k(0)<k(e)<1$ & $k(e)<1$ & $k(0)<k(e)<1$ & $k(0)<k(e)<1$ \\
\hline $\begin{array}{l}\text { Use of impure } \\
\text { silicon }\end{array}$ & no & yes & yes & $\begin{array}{l}\text { with } \\
\text { restrictions }\end{array}$ & ? \\
\hline $\begin{array}{l}\text { Areas of } \\
\text { concern }\end{array}$ & $\begin{array}{c}\text { impurities., } \\
\text { stresses }\end{array}$ & $\begin{array}{r}\text { bowing } \\
\text { stresses }\end{array}$ & $\begin{array}{l}\text { impurities, } \\
\text { structure }\end{array}$ & $\begin{array}{l}\text { width, } \\
\text { stresses }\end{array}$ & $\begin{array}{l}\text { stability。 } \\
\text { control }\end{array}$ \\
\hline
\end{tabular}

Table 6. Growth characteristics of sheet methods that can produce solar cells with greater than $13.5 \%$ efficiency

\begin{tabular}{|c|c|c|c|c|c|}
\hline & EFG & ES P & RAD & WEB & $\mathrm{CFH}$ \\
\hline $\begin{array}{c}\text { Growth rate } \\
(\mathrm{cm} / \mathrm{min})\end{array}$ & 2 & 2 & 10 & 2 & 2 \\
\hline width (cm) & 45 & 10 & 10 & 6 & 2 \\
\hline $\begin{array}{c}\text { Typical thickness } \\
\text { (microns) }\end{array}$ & 200 & 200 & 80 & 160 & 2000 \\
\hline Maximum length (m) & 30 & 1 & 30 & 11 & 0.03 \\
\hline $\begin{array}{l}\text { Crystal } \\
\text { structure }\end{array}$ & $\begin{array}{l}\text { twins, grain } \\
\text { boundaries }\end{array}$ & $\begin{array}{l}\text { large } \\
\text { grains }\end{array}$ & $\begin{array}{l}\text { narrow } \\
\text { grains }\end{array}$ & $\begin{array}{c}\text { single } \\
{[(I I I) \text { twin] }}\end{array}$ & $\begin{array}{l}\text { large } \\
\text { grains }\end{array}$ \\
\hline $\begin{array}{l}\text { Solar cell } \\
\text { efficiency ( })\end{array}$ & 14 (12) & $14 \quad(12)$ & 13.5 (11) & $16(13)$ & $15(13)^{*}$ \\
\hline Technology/skill & high & low & low & high & high \\
\hline
\end{tabular}

*Assumes a 438 AR coating improvement [uncoated values are 10.7 (9.7)].

The RAD process ${ }^{8}$ also involves the use of graphite to assist in ribbon shaping. Here, a specially prepared graphite ribbon (with a pyrolytic graphite surface) is continuously passed upward through a slot in the bottom of a quartz crucible. Thin layers of silicon adhere and sclidify on both sides of the graphite substrate. After growth, the graphite is burned away, leaving two silicon ribbons about $5 \mathrm{~cm}$ wide (for a total effective width of lo $\mathrm{cm})$. The characteristics of the RAD process are given in Tables 5 and 6 . Some of the main attributes of RAD growth are easy thermal control, moderately high growth rates, and thin flat ribbons. Some disadvantages are carbon impurities and the need for a special substrate. Although a fine, parallel, longitudinal grain structure is present, it is still possible to achieve cell efficiencies over $13 \%$ with this process. 


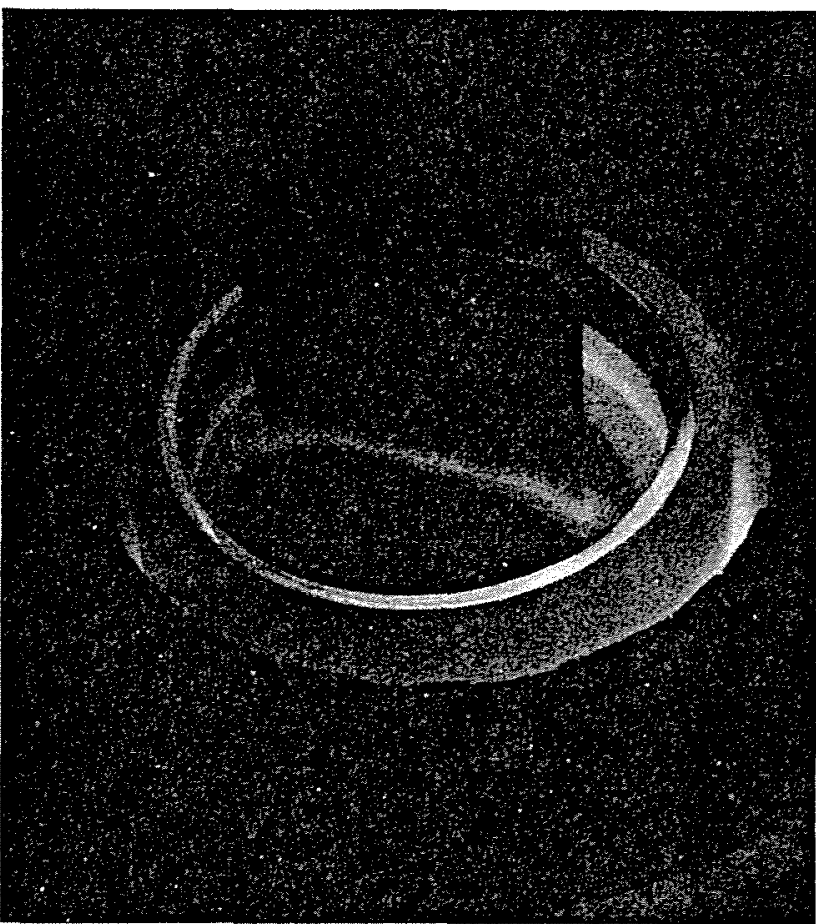

Figure 11. Hot zone for ESP growth.

Dendritic web solidificationlo is initiated by inserting a thin, narrow dendrite of silicon (a crystallographic structure containing a plurality of parallel (1ll) twins. parallel to its narrow faces that propagates in a 〈II2> growth direction and has edges in $\langle\bar{l} \overline{0}\rangle$ directions from its axis) in the liquid silicon. Heat shields immediately above the melt have shaped openings that define an elongated growth zone. As melt temperature is lowered, an elongated button of silicon spreads from the dendrite's tip in the growth zone. When the button width approaches a substantial fraction of the desired ribbon width, the dendrite is systematically pulled upward as the melt temperature is again increased. Two coplanar dendrites are thereby formed, one at each edge of the button. They continue to grow downward into supercooled melt regions and $a$ web of silicon solidifies between them. The (111) twin structures penetrate both dendrites and the web itself (see Figure 9). Otherwise, the web is a single (but dislocated) crystal. The main advantages of web growth are good crystal quality and high solar cell efficiencies. Figure 12 shows that module efficiencies over 138 are attainable with web solar cells. Some of the problems facing the web process are difficulty of wide growth, the need for close thermal control, and maintaining a nondisruptive growth environment for the relatively complex growth mechanism. The dendritic web technique is the oldest and one of the most developed of the silicon ribbon growth methods.

CFH growthll is a relatively new method that is now only in a feasibility demonstration stage. Here, the top surface of a rotating, large-diameter, cylindrical, polycrystalline silicon rod is melted by a C-shaped induction heating coil, as shown in Figure lo. Because of the coil geometry, the portion of the rod top that rotates under the enclosed area of the coil is actively heated, while the portion that is outside the enclosed area (i.e., in the
The ESP growth technique 9 (also sometimes called edge-stabilized ribbon or ESR) passes two parallel filaments upward through silicon in a crucible. Where they emerge, they are bridged by a seed crystal or wettable bar. Solidification takes place first on the bridge and then continuously on the bottom of the ribbon as the filament/ribbon assembly is moved upward. The filaments provide edge definition for the meniscus and are attached to the ribbon's edges. A variety of filament materials with small-to-medium liquid silicon contact angles can be used, including graphite, graphite yarn, sic fibers, mulite, and quartz fibers. The ESP shaping method has a less detrimental effect on grain nucleation than die or sheet substrate shaping, and larger grains are obtained. The ESP process has the advantages of easy thermal control along with a simple hot-zone configuration (see Figure 11). Solar cell efficiencies about 908 of those of Cz-grown controls are obtained. Disadvantages include thermal stresses and low growth rates (both of which are characteristic of most of the ribbon growth methods) and the need for filaments.

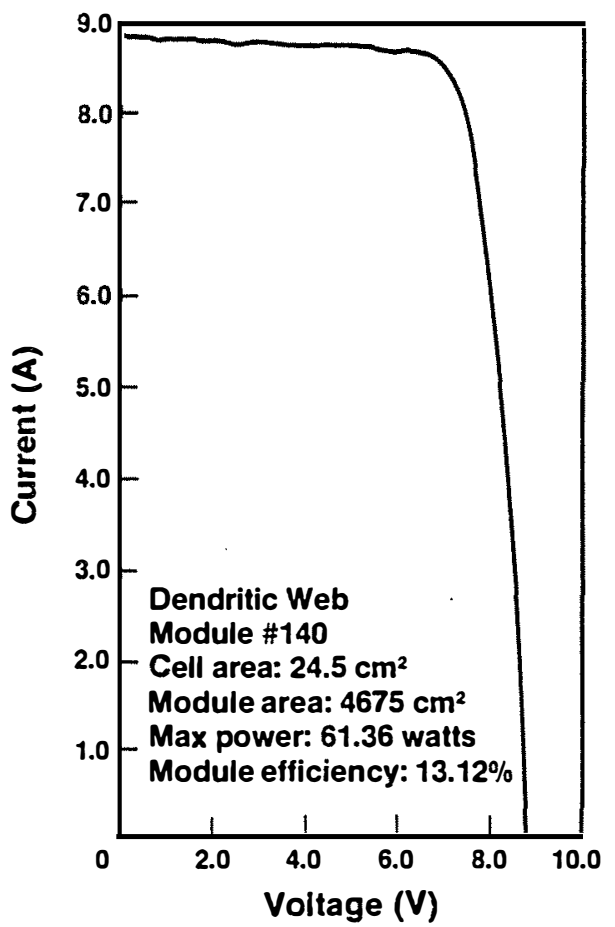

Figure 12. I $N$. Characteristics of a dendritic web solar cell module. 
open C-shaped region) is not. The temperature difference between the two $r$ egions is determined by the rod's rotation rate. Horizontal ribbon growth takes place in the cooler open region. Two effects define the leading edge of the ribbon. One is the temperature gradient between the two regions. The other is the depression of the melt surface by magnetic repulsion under the coil. A relatively high, cool growth mesa is present in the opening of the C-shaped region, while the region under the coil tubing is a warmer, depressed valley. The advantages of $\mathrm{CFH}$ growth are high purity (there is no crucible, die, filament, or substrate), high solar cell efficiencies, low thermal convection due to the shallow melt, and potentially high growth rates (yet to be demonstrated) allowed by the large-area solid/liquid interface. Anticipated difficulties include problems with the stability and control of the lower meniscus edge and scale-up to wide ribbons.

Summary and discussion

The role of silicon as a moderately high-efficiency photovoltaic material was examined in this review. The current conventional technology for processing silicon from sand to crystals was presented, and some specific crystal growth techniques were analyzed." Because of the current trend toward high efficiencies, only dislccation-free ingot growth methods (CZ, FZ, and CC) were covered. Similarly, only ribbon growth methods that have published efficiencies greater than 13.58 were dealt with. There are of course, numerous other approaches to both ingot and sheet growth that were not included in this paper. However, many of these have already been reviewed.12,13 Although the solar cell efficiencies resulting from these processes are lower, many of the techniques have the potential of being low in cost. There are also crystal growth processes under develonment for which recent results have not been published. Some of these may yield high-efficiency cells.

For high-efficiency devices, crystallographic defects and impurities are of concern, since they directly affect cell performance through lowered minority carrier lifetimes. Other important parameters are high throughput, easy control, and flat, smooth surfaces (i.e., for sheets). None of the present growth methods have all of these desirable attributes, although each has some of them. Perhaps the ideal crystal growth method for pV silicon is yet to be discovered.

\section{Peferences}

1. Mason, B., Principles of Geochemistry, Wiley (New York) 1952.

2. Hartley, J. N.. World Mineral and Energy Resources - Some Facts and Assessments, Battelle Monograph series, vo. $\overline{6, \text { Battelle office }}$ of cordorate communications (Columbus) 1974 .

3. Green, M. A., Blakers, A. W., Jiqun, S。, Keller, E. M., Wenham, S. R., Godfrey, R。 B., Szpitalak, T., and Willison, M. R., "Towards a 208 Efficient Silicon Solar Cell," in: $17^{\text {th }}$ IEEE Photovoltaic Snecialists Conference Record, Orlando, FL, 1984 (IEEE, New York 198 4) pp 386-389.

4. Taylor, R., "Photovoltaic System Requirements: Central and Distributed Applications," EPRI Conference Proceedings: Solar and Wind Power--1982 Status and Outlook, EPRI AP-288 4-SR, Electr $\overline{1 C}$ Power Research Institute, Palo Alto, CA 1983.

5. Ciszek, T. F., "Some Applications of Cold Crucible Technology for Silicon photovoltaic Material Preparation," J。 Electrochem. Soc., Vol. 132, pp. 963-968. 1985.

6. Wald, F., "Crystal Growth of Silicon Ribbons for Terrestrial solar Cells by the EFG Method," in: Crystals: Growth, Properties, and Applications, Vol. 5, Ed. J. Grabmaier (Springer, Beriñ) pp。 147-198. 1981.

7. Ciszek, T. F., ibid, pp.109-146. 1981 .

8. Belouet, C., Texier-Hervo, C., Mautref, M., Belin, C., Paulin, J. and Schneider, J., "Growth of polysilicon sheets on a Carbon shaper by the RAD process," J. Crystal Growth, Vol. 61, Pp. 615-628. 1983.

9. CIszek, T. F.. "The Growth of Silicon Ribbons for Photovoltaics by Edge-supported Pulling," in: Silicon Processing for Photovoltaics, Eds. C. P. Khattak and K. V. Ravi (Elsevier science pubiishers) pp. I3I-165. 1985.

10. Seidensticker, R. G. "Dendritic फeb Growth of Silicon," in: Crystals: Growth, Properties, and Applications, Vol. 8, Ed. J. Grabmaier (Springer, Berlin) pp。 145-172. $198 \overline{2}$

11. Ciszek, T. F., "Solid/Melt Interface Studies of High-Speed Silicon Sheet Growth," Final Technical progress Report, DOE/JPL contract W08746-83-1, SERI Report No. PR-212-2634。 1985.

12. Ciszek, T. F., "Techniques for the Crystal Growth of silicon Ingots and Ribbons," J. Crystal Growth, Vol. 66, pp. 655-672. 1984 .

13. Ciszek, T.F., "Silicon for Solar Cells," in: Crystal Growth of Electronic Materials, Ed. E. Kaldis (Elsevier Science Fublishers) 1985 (in press). 